\title{
The type and duration of use of removable dentures in seniors over 65 years of age from Lublin in Poland
}

\begin{abstract}
Introduction. Age-related tooth loss causes an increasing need for prosthetic treatment. Maintaining a healthy masticatory system, as well as proper speaking functions is one of the main goals for prosthetic rehabilitation of the elderly.

Aim. The authors aimed at checking what types of moveable dentures people over 65 , residents of nursing and family homes tend to wear and how long do they do it.

Material and methods. Some 240 people over 65 were looked at - 117 were residents of nursing homes in Lublin, while another 123 lived in their own family home. The authors took the following factors into consideration: type of denture, and how long were the dentures used.

Results. It appeared that movable dentures were used by some $57.26 \%$ of nursing home residents and $69.11 \%$ of people living in their family homes. Residents used mostly full denture, both in maxilla and mandible, respectively $71.05 \%$ and $67.14 \%$. Similarly, seniors living at home had worn mainly full maxillary denture in $50.00 \%$ of cases, and full mandibular denture in $44.44 \%$ of cases. The mean time of using maxillary and mandibular dentures was longer in seniors residing in nursing homes (maxilla -7.24 years, mandible -7.48 years) than in persons living with their families (maxilla -5.39 years, mandible -4.63 years).

Conclusion. The supply of dentures in both groups of seniors is unsatisfactory. Most of the examined seniors have used the dental prostheses for too long.
\end{abstract}

Keywords: geriatric dentistry, elders, dentures, nursing homes.

DOI: $10.1515 /$ pjph-2016-0007

\section{INTRODUCTION}

During the last few decades there was a significant increase in life expectancy among the elderly population [1-5]. According to the data of 2002, there are about 600 million people aged 60 years and older living in the world, and this number is expected to grow to about 2 billion in 2050 [3]. These demographic changes mainly happen to developed countries, yet a lifespan increase can be observed in Poland as well. Many factors influence the increase in the number of elderly population. They include the development of modern medicine, the use of new methods of treatment and therapeutic measures as well as modern equipment and apparatus. Promoting a healthy lifestyle takes into account the proper, balanced diet, active outdoor activities, limiting the use of stimulants, drugs, alcohol and smoking, and contributes to improving the well-being and maintaining health for many years. The improvement of socio-economic and living conditions also contributes to the increase in longevity $[1,2]$. Not without significance is the impact of declining number of births of children in recent years $[6,7]$.

The increase in the number of elderly people led to the necessity of paying more attention to issues of seniors. This pertains to issues related to socio-economic, political and health factors $[3,4]$. Hence, the interest in gerontology, geriatrics, and gero- dentistry (a fresh invention of geriatrics) has increased. With the body's aging processes, many changes happen both to the face and the stomatognathic system. Many a time, pathological processes are superimposed on those of the physiological nature and are difficult to distinguish. Knowing them makes dental management easier. Periodontal diseases and caries and its complications are considered the main causes of the loss of teeth in the elderly [8]. As the result of an imbalance between the activity of osteoblasts and osteoclasts it promotes and accelerates bone atrophy and, concerns mainly the alveolar part of the mandibular body and maxillary alveolar ridge [1].

Teeth loss increases the demand for prosthetic treatment. There is a whole variety of the masticatory system reconstruction and rehabilitation methods, from the most commonly used, but not the most favorable removable partial and complete overlay dentures to the implant treatment. They are primarily aimed at restoration of normal chewing function, as well as articulation and aesthetic look.

\section{AIM}

Evaluating the type and duration of using removable dentures in people over 65 years of age residing in Lublin regarding the place of living - nursing or family homes. 


\section{MATERIAL AND METHODS}

The study was conducted in Lublin, a city situated in southeast part of Poland (Europe). The population of the public care homes was analyzed for this study. The inclusion criteria were age over 65 or above and lack of signs of acute illness. All patients have been proben to maintain good contact with the environment and be physically and have been mentally fit to give their informed consent for participation in the study. It meant a total of 117 subjects who were included in this study. Of these, 57 were male and 60 female residents. An oral examination was performed by one dentist, using a mouth mirror and probe and revealed the presence of removable dentures. The type of used dentures (separately for maxilla and mandible) as partial denture or full denture was also confirmed. Situations where patients have dentures but do not use them were noted as well. After examination seniors were asked about the duration of having prosthetic dental restorations (separately for maxilla and mandible): 0-5 years; $6-10$ years and over 10 years. Similar criteria were applied for the comparative group of patients aged 65+ years, attending University Dental Center, Medical University of Lublin seeking dental treatment but living in their family homes in Lublin. The group comprised 123 seniors, 63 men and 60 women. The study protocol was reviewed and fully approved by the Bioethics Committee of the Medical University of Lublin, Poland. The results were statistically analyzed and the chi-square test was performed to evaluate the differences. The results were considered significant at $\mathrm{p}<0.05$.

\section{RESULTS}

The investigations showed that removable dentures were used by $57.26 \%$ of nursing home residents and by $69.11 \%$ of those living with the family (Table 1 ). The residents of nursing homes were most likely to use a complete denture in the maxilla, i.e. $71.05 \%$, less frequently the partial one $-17.1 \%$ and $11.84 \%$ had dentures but were not using them. In the group of seniors living with their families also most frequently they used complete dentures. The residents of nursing homes and living with their families also in mandible most frequently were using complete dentures, respectively $67.14 \%$ and $44.44 \%$. The statistical analysis proved significant differences in the type of used dentures in the maxilla and mandible between the groups (Table 2).

The research shows that that women living in nursing homes were using complete dentures in the maxilla more often $-70.73 \%$ compared to the women living with families $-49.02 \%$. The differences were not statistically significant (Table 3). Yet, the male residents of nursing homes in Lublin were much more likely to use complete dentures in the maxilla $(71.43 \%)$ than the respondents reporting to University Dental Center $-51.28 \%$ (Table 4 ) The statistical analysis confirmed significant differences in the type of used dentures in the mandible among the women from nursing homes and University Dental Center. The female residents of nursing homes were using complete dentures $-75.00 \%$ more often that the women living in their family homes- $42.86 \%$ (Table 3). However, the men reporting to University Dental Center in Lublin slightly more often were using partial dentures in the mandible $-37.50 \%$ than the men from nursing homes $17.65 \%$ (Table 4 ).

The mean length of using the dentures in the maxilla among the residents of nursing home was 7.24 years, and was slightly longer than among the seniors living with their families -5.39 years.
TABLE 1. Number and percentage of people using removable dentures in study groups from regard to the place of residence.

\begin{tabular}{cccc}
\hline \hline \multirow{2}{*}{ Group } & Yes & No & Total \\
\cline { 2 - 4 } & $\mathbf{n}$ & $\mathbf{n}$ & $\mathbf{n}$ \\
& $\mathbf{\%}$ & $\mathbf{\%}$ & $\mathbf{\%}$ \\
\hline \multirow{2}{*}{ Nursing homes } & 67 & 50 & 117 \\
& $57.26 \%$ & $42.74 \%$ & $100.00 \%$ \\
\hline \multirow{2}{*}{ Family homes } & 85 & 38 & 123 \\
& $69.11 \%$ & $30.89 \%$ & $100.00 \%$ \\
\multirow{2}{*}{ Total } & 152 & 88 & 240 \\
& $63.33 \%$ & $36.67 \%$ & $100.00 \%$ \\
\hline
\end{tabular}

Statistical analysis: $\mathrm{Chi}^{2}=3.62 ; \mathrm{p}=0.06$

TABLE 2. Number and percentage of subjects with regard to the use of dental prostheses in the maxilla and the mandible, and the place of residence.

\begin{tabular}{|c|c|c|c|c|c|c|c|c|}
\hline \multirow{3}{*}{ Type of denture } & \multicolumn{4}{|c|}{ Maxilla } & \multicolumn{4}{|c|}{ Mandible } \\
\hline & \multicolumn{2}{|c|}{$\begin{array}{l}\text { Nursing } \\
\text { homes }\end{array}$} & \multicolumn{2}{|c|}{$\begin{array}{l}\text { Family } \\
\text { homes }\end{array}$} & \multicolumn{2}{|c|}{$\begin{array}{l}\text { Nursing } \\
\text { homes }\end{array}$} & \multicolumn{2}{|c|}{$\begin{array}{l}\text { Family } \\
\text { homes }\end{array}$} \\
\hline & $\mathbf{n}$ & $\%$ & $\mathbf{n}$ & $\%$ & $\mathbf{n}$ & $\%$ & $\mathbf{n}$ & $\%$ \\
\hline Partial denture & 13 & $17.11 \%$ & 37 & $41.11 \%$ & 14 & $20.00 \%$ & 30 & $37.04 \%$ \\
\hline $\begin{array}{l}\text { Complete } \\
\text { denture }\end{array}$ & 54 & $71.05 \%$ & 45 & $50.00 \%$ & 47 & $67.14 \%$ & 36 & $44.44 \%$ \\
\hline \multirow[t]{2}{*}{$\begin{array}{l}\text { Has - but does } \\
\text { not use }\end{array}$} & 9 & $11.84 \%$ & 8 & $8.89 \%$ & 9 & $12.86 \%$ & 15 & $18.52 \%$ \\
\hline & \multicolumn{4}{|c|}{$\begin{array}{l}\text { Statistical analysis: } \\
\mathrm{Chi}^{2}=11.29 ; \mathrm{p}=0.004 *\end{array}$} & \multicolumn{4}{|c|}{$\begin{array}{l}\text { Statistical analysis: } \\
\mathrm{Chi}^{2}=8.02 ; \mathrm{p}=0.02 *\end{array}$} \\
\hline
\end{tabular}

TABLE 3. Number and percentage of surveyed women with regard to the use of dental prostheses in the maxilla and the mandible and the place of residence.

\begin{tabular}{|c|c|c|c|c|c|c|c|c|}
\hline \multirow{3}{*}{$\begin{array}{l}\text { Type of } \\
\text { denture }\end{array}$} & \multicolumn{4}{|c|}{ Maxilla } & \multicolumn{4}{|c|}{ Mandible } \\
\hline & \multicolumn{2}{|c|}{$\begin{array}{c}\text { Nursing } \\
\text { homes }\end{array}$} & \multicolumn{2}{|c|}{$\begin{array}{l}\text { Family } \\
\text { homes }\end{array}$} & \multicolumn{2}{|c|}{$\begin{array}{l}\text { Nursing } \\
\text { homes }\end{array}$} & \multicolumn{2}{|c|}{$\begin{array}{l}\text { Family } \\
\text { homes }\end{array}$} \\
\hline & $=\frac{\Xi}{\stackrel{\Xi}{\Xi}}$ & $\%$ & $=\frac{\bar{\Xi}}{\bar{\Xi}}$ & $\%$ & $=\stackrel{\Xi}{0}$ & $\%$ & $=\stackrel{\Xi}{\Xi}$ & $\%$ \\
\hline $\begin{array}{l}\text { Partial } \\
\text { denture }\end{array}$ & 10 & $24.39 \%$ & 23 & $45.10 \%$ & 8 & $22.22 \%$ & 18 & $36.73 \%$ \\
\hline $\begin{array}{l}\text { Complete } \\
\text { denture }\end{array}$ & 29 & $70.73 \%$ & 25 & $49.02 \%$ & 27 & $75.00 \%$ & 21 & $42.86 \%$ \\
\hline \multirow[t]{2}{*}{$\begin{array}{l}\text { Has - but } \\
\text { does not use }\end{array}$} & 2 & $4.88 \%$ & 3 & $5.88 \%$ & 1 & $2.78 \%$ & 10 & $20.41 \%$ \\
\hline & \multicolumn{4}{|c|}{$\begin{array}{l}\text { Statistical analysis: } \\
\mathrm{Chi}^{2}=5.58 ; \mathrm{p}=0.10\end{array}$} & \multicolumn{4}{|c|}{$\begin{array}{c}\text { Statistical analysis: } \\
\mathrm{Chi}^{2}=10.21 ; \mathrm{p}=0.006^{*}\end{array}$} \\
\hline
\end{tabular}

TABLE 4. Number and percentage of surveyed men with regard to the use of dental prostheses in the maxilla and the mandible, and the place of residence.

\begin{tabular}{|c|c|c|c|c|c|c|c|c|}
\hline \multirow{3}{*}{$\begin{array}{l}\text { Type of } \\
\text { denture }\end{array}$} & \multicolumn{4}{|c|}{ Maxilla } & \multicolumn{4}{|c|}{ Mandible } \\
\hline & \multicolumn{2}{|c|}{$\begin{array}{l}\text { Nursing } \\
\text { homes }\end{array}$} & \multicolumn{2}{|c|}{$\begin{array}{l}\text { Family } \\
\text { homes }\end{array}$} & \multicolumn{2}{|c|}{$\begin{array}{l}\text { Nursing } \\
\text { homes }\end{array}$} & \multicolumn{2}{|c|}{$\begin{array}{l}\text { Family } \\
\text { homes }\end{array}$} \\
\hline & $\begin{array}{c}\mathbf{n} \\
\text { men }\end{array}$ & $\%$ & $\begin{array}{c}\mathbf{n} \\
\text { men }\end{array}$ & $\%$ & $\begin{array}{c}\mathbf{n} \\
\text { men }\end{array}$ & $\%$ & $\begin{array}{c}n \\
\text { men }\end{array}$ & $\%$ \\
\hline $\begin{array}{l}\text { Partial } \\
\text { denture }\end{array}$ & 3 & $8.57 \%$ & 14 & $35.90 \%$ & 6 & $17.65 \%$ & 12 & $37.50 \%$ \\
\hline $\begin{array}{l}\text { Complete } \\
\text { denture }\end{array}$ & 25 & $71.43 \%$ & 20 & $51.28 \%$ & 20 & $58.82 \%$ & 15 & $46.87 \%$ \\
\hline \multirow[t]{2}{*}{$\begin{array}{l}\text { Has - but } \\
\text { does not use }\end{array}$} & 7 & $20.00 \%$ & 5 & $12.82 \%$ & 8 & $23.53 \%$ & 5 & $15.63 \%$ \\
\hline & \multicolumn{4}{|c|}{$\begin{array}{l}\text { Statistical analysis: } \\
\mathrm{Chi}^{2}=7.81 ; \mathrm{p}=0.02 *\end{array}$} & \multicolumn{4}{|c|}{$\begin{array}{l}\text { Statistical analysis: } \\
\mathrm{Chi}^{2}=3.35 ; \mathrm{p}=0.19\end{array}$} \\
\hline
\end{tabular}


TABLE 5. Average time (years) of the use of dental prostheses in the maxilla and the mandible in the study groups with regard to the place of residence.

\begin{tabular}{ccccc}
\hline \hline \multirow{2}{*}{ Group } & \multicolumn{2}{c}{ Maxilla } & \multicolumn{2}{c}{ Mandible } \\
\cline { 2 - 5 } & $\begin{array}{c}\text { Average } \\
\text { duration }\end{array}$ & $\begin{array}{c}\text { Standard } \\
\text { Deviation }\end{array}$ & $\begin{array}{c}\text { Average } \\
\text { duration }\end{array}$ & $\begin{array}{c}\text { Standard } \\
\text { Deviation }\end{array}$ \\
\hline Nursing homes & 7.24 years & 5.82 & 7.48 years & 6.30 \\
\hline Family homes & 5.39 years & 4.14 & 4.63 years & 3.75 \\
\hline & \multicolumn{2}{c}{$\begin{array}{c}\text { Statistical analysis: } \\
\mathrm{Z}=-1.78 ; \mathrm{p}=0.07\end{array}$} & \multicolumn{2}{c}{$\begin{array}{c}\text { Statistical analysis: } \\
\mathrm{Z}=-2.70 ; \mathrm{p}=0.007 *\end{array}$} \\
\hline
\end{tabular}

The differences were not statistically significant. However the mean time of using dentures in the maxilla was statistically significantly longer ( 7.48 years) in the group of nursing home residents than among the seniors reporting to University Dental Center (4.63 years), (Table 5). The nursing home residents were most likely to use dentures in the maxilla for up to 5 years $-58.21 \%$, however as much as $22.39 \%$ of the seniors were using the dentures for over 10 years, and $19.40 \%$ for $6-10$ years. In the group of seniors living with their families also the majority used the dentures in the maxilla up to 5 years $-63.41 \%$, however $26.83 \%$ of the patients for 6-10 years, and $9.76 \%$ for over 10 years. The statistical analysis did not confirm any differences in the duration of using dentures in the upper jaw between the groups. One woman living in a nursing home in Lublin has used a denture for some 30 years (Table 6). The respondents from the nursing homes most frequently were using dentures in the mandible for up to 5 years $(60.66 \%)$, but as much as $24.59 \%$ were using dentures for over 10 years, and $14.75 \%$ of respondents were using dentures for 6-10 years. In the group of seniors living with their families, they were using significantly more frequently dentures in the mandible for 5 years $-74.24 \%$ and $19.70 \%$ of seniors were using their dentures for $6-10$ years, and $6.06 \%$ for over 10 years. Fourtimes more residents of nursing homes were using their dentures for over 10 years as compared to the seniors living with their families. Statistical analysis confirmed significant differences in the duration of using dentures in the mandible between the groups. One of the nursing home residents was wearing her denture in the lower jaw for 30 years (Table 6).

\section{DISCUSSION}

Teeth loss is considered to be one of the symptoms of body's ageing [4]. Usually, it affects the elderly population and requires some dentures/overlays to be used. Although the elderly population is more likely to retain their teeth, toothlessness remains serious problem among seniors. According to the data provided by the WHO, some $54.6 \%$ of people over 75 are toothless. Lack of the overlays or presence of inadequate dentures in case of total toothlessness, may cause psychical trauma related to restriction in the ability to chew and may disorder body functions as well as favor oral health pathology [2,9].

The data presented here is different from data valid for other parts of Poland. For instance, in case of residents of nursing homes located in Szczecin and neighboring towns, most people were using partial removable dentures both in the maxilla $-66.4 \%$ and in mandible $-67.23 \%$, while only some $31.2 \%$ used complete dentures in the maxilla and $29.41 \%$ in the mandible. A small proportion of seniors had cast partial dentures: $2.4 \%$ in maxilla and $3.36 \%$ in the mandible. Some $71.05 \%$ of the residents of nursing homes in Lublin used complete upper dentures, while $67.14 \%$ had complete lower denture. It is worth mentioning that no single respondent used a cast partial denture. These discrepancies might be caused by the fact that in case of the residents of nursing homes in Szczecin, toothlessness happened to some $20 \%$ of the respondents only, while some $56.41 \%$ of the residents of Lublin nursing homes had no teeth at all [10]. Yet, in Bydgoszcz, the proportion of nursing home residents using removable acrylic dentures was $81.40 \%$. The authors of the study did not include individuals wearing cast partial dentures in the group [11]. In addition, some $70 \%$ of the residents of nursing homes in Poznań used partial or complete dentures [12]. Some similar results were found among the residents of nursing homes in Gdańsk some $17.10 \%$ of seniors used partial denture in the maxilla, while another $19.00 \%$ used mandibular dentures. However, a two-fold lower number of complete dentures was confirmed: $35.20 \%$ of seniors had a complete denture in the maxilla and $28.60 \%$ - in the mandible [13]. Namiot et. al. have made some totally different findings - they noticed that some $26.20 \%$ of the respondents wore maxillary dentures and $29.70 \%$ wore mandibular dentures [14].

A lower proportion of persons using removable dentures than in our research was confirmed among the residents of nursing homes in other countries too. For instance, in Iran $47.1 \%$ [15] and Croatia, where the complete denture in maxilla was noted in $54 \%$ of the respondents and in the mandible $-42.4 \%$, and a partial denture in maxilla was confirmed in $12.9 \%$ of seniors and in the mandible $-15.1 \%$ [16]. A higher number of individuals using removable dentures was noticed in nursing homes in Austria - 69\% [17] and in Avon in Great Britain $-80.40 \%$. In case of nursing homes located in Turkish capital, Ankara, some $55.5 \%$ of seniors had a complete, while $11.9 \%$ had no denture at all, even though they had no teeth [5]. However, in the residents of nursing homes in Germany (Berlin), $88.4 \%$ of them had a partial upper denture and $82.9 \%$ had a lower denture, while $75.1 \%$ had a complete upper denture and $58.4 \%$ - a lower denture [19]. Approximately $20 \%$ of

TABLE 6. Duration of the use of dental prostheses in the maxilla and the mandible in the study groups with regard to the place of residence.

\begin{tabular}{|c|c|c|c|c|c|c|c|c|}
\hline \multirow{3}{*}{ Group } & \multicolumn{4}{|c|}{ Maxilla } & \multicolumn{4}{|c|}{ Mandible } \\
\hline & $<5$ years & 6-10 years & $>10$ years & Total & $<5$ years & 6-10 years & $>10$ years & Total \\
\hline & $\begin{array}{l}\text { n } \\
\%\end{array}$ & $\begin{array}{c}\text { n } \\
\%\end{array}$ & $\begin{array}{c}\text { n } \\
\%\end{array}$ & $\begin{array}{c}\mathbf{n} \\
\%\end{array}$ & $\begin{array}{c}\text { n } \\
\%\end{array}$ & $\begin{array}{c}\mathbf{n} \\
\%\end{array}$ & $\begin{array}{c}\text { n } \\
\%\end{array}$ & $\begin{array}{c}\text { n } \\
\%\end{array}$ \\
\hline Nursing homes & $\begin{array}{c}39 \\
58.21 \%\end{array}$ & $\begin{array}{c}13 \\
19.40 \%\end{array}$ & $\begin{array}{c}15 \\
22.39 \%\end{array}$ & $\begin{array}{c}67 \\
100.00 \%\end{array}$ & $\begin{array}{c}37 \\
60.66 \%\end{array}$ & $\begin{array}{c}9 \\
14.75 \%\end{array}$ & $\begin{array}{c}15 \\
24.59 \%\end{array}$ & $\begin{array}{c}61 \\
100.00 \%\end{array}$ \\
\hline Family homes & $\begin{array}{c}52 \\
63.41 \%\end{array}$ & $\begin{array}{c}22 \\
26.83 \%\end{array}$ & $\begin{array}{c}8 \\
9.76 \%\end{array}$ & $\begin{array}{c}82 \\
100.00 \%\end{array}$ & $\begin{array}{c}49 \\
74.24 \%\end{array}$ & $\begin{array}{c}13 \\
19.70 \%\end{array}$ & $\begin{array}{c}4 \\
6.06 \%\end{array}$ & $\begin{array}{c}66 \\
100.00 \%\end{array}$ \\
\hline Total & $\begin{array}{c}91 \\
61.07 \%\end{array}$ & $\begin{array}{c}35 \\
23.49 \%\end{array}$ & $\begin{array}{c}23 \\
15.44 \%\end{array}$ & $\begin{array}{c}149 \\
100.00 \%\end{array}$ & $\begin{array}{c}86 \\
67.72 \%\end{array}$ & $\begin{array}{c}22 \\
17.32 \%\end{array}$ & $\begin{array}{c}19 \\
14.96 \%\end{array}$ & $\begin{array}{c}127 \\
100.00 \%\end{array}$ \\
\hline
\end{tabular}


the residents of nursing homes in Australia did not use their dentures despite having them [20].

Judging by the authors' own research, it can be concluded that $69.11 \%$ of the surveyed population in Lublin had removable dental prosthetic restorations. Residents of nursing homes in Wrocław were much more likely to use removable overlay dentures - 89\% [21]. In Bydgoszcz region, some 91.40\% of the nursing homes population used dental prosthetic restorations. It is worth mentioning that as much as $27.10 \%$ of Bydgoszcz UTA students used cast partial dentures [11]. Patients admitted to University Dental Center in Lublin had no cast partial dentures. Patients of the Department of Conservative Dentistry, Medical University of Lodz reported similar results $-71 \%$ of them [22] used dental prosthetic restorations. In case of fit, independent residents of Kraków, it was $63.43 \%$ [23].

In Japan, some $67 \%$ of people used dental prosthetic restorations [24], in Lithuania 32\% [25] and in Sri Lanka 22\% (Negambo) [26] and 18\% (Moratuwa) [27]. Among the respondents from India, $8.3 \%$ of seniors used complete dentures in one or both dental arches, $6.5 \%$ - partial dentures, while $67.6 \%$ did not have any dental prosthetic restorations [28]. In contrast, $73.1 \%$ of the population of south-eastern Brazil (Batucatu) used a complete upper denture and $43.3 \%$, - the lower one while $4.6 \%$ - a partial upper denture, and $12.6 \%$ - the lower one [29]. Just as in our study, quite a large group of people using dental prosthetic restorations for more than 10 years was noted among the residents of Szczecin nursing homes: $25.6 \%$ of seniors had upper denture and $26.05 \%$ - the lower one. Prostheses in the upper jaw most frequently were used for $6-10$ years $-37.6 \%$ of respondents, and in the lower jaw up to 5 years $-38.65 \%$ of the respondents [10]. Residents of Lublin nursing homes most frequently used dental prosthetic restorations up to five years in both the maxilla $-58.21 \%$ and in the mandible $-60.66 \%$, while the average duration of using dental prostheses in the maxilla was 7.24 years and in mandible -7.48 years. The average lifetime of dental prosthetic restorations longer than in our study was reported among the residents of nursing home from Poznan and the surrounding area, in whom it was 11 years - ranging from 1 up to 40 years [30], as well as in 2 of nursing homes in Bydgoszcz - 12.80 years [11]. Duration of using dental prostheses by residents of nursing home in Gdansk ranged from 0.5 years to 52 years. Dentures used for up to five years accounted for $28.5 \%$, from 6 to 10 years $-37.10 \%$, for $11-20$ years $-27.6 \%$, and over 20 years $-6.7 \%$ [13]. One of the residents of Lublin nursing homes had a complete upper and lower denture for 30 years. In Croatia, $39.6 \%$ of nursing home residents were using dentures for more than 15 years, and only $6.5 \%$ - for up to 5 years [16], while in Germany (Berlin) $15.6 \%$ of seniors were using dental prosthetic restorations for more than 30 years, $20.8 \%$ for $21-30$ years, and only $26.3 \%$ had dentures for less than 10 years [19]. Among nursing home residents in Turkey (Istanbul) $26 \%$ of people had dentures for more than 8 years [31].

Seniors living in their family homes in Lublin, most frequently were using dental prosthetic restorations up to five years in both the maxilla (63.41\%) as well as in the lower jaw (74.24\%), and the average time was 5.39 years for the maxilla and 4.63 years for mandible. On average, patients of the Outpatient Clinic and Department of Geriatrics, University Hospital in Bydgoszcz - 9.20 years [11], in patients of the Department of Prosthodontics of Pomeranian Medical Uni- versity in Szczecin - 13 years for women, and 8 years and 6 months for men [32] and also in subjects from Greece - 11.5 years in the range of $1-34$ years [33] used dental prostheses longer than the subjects of our study. Students of UTA in Bydgoszcz used dental prosthetic restorations similarly to Lublin residents - for 4.60 years on average [11]. Patients admitted to the Department of Prosthodontics, Wroclaw Medical University, reported to have used dental prosthetic restorations from 4 to 20 years [21], similarly to patients from Białystok $-1-24$ years [34]. Residents of Kraków used prostheses for much shorter - 3-10 years [35]. In contrast, a higher proportion of people using dental prosthetic restorations for more than 10 years was observed in seniors from the north-eastern macro region of Poland: for more than 15 years $-14.4 \%$, for $11-15$ years $-15.1 \%$, for $5-10$ years $-33.2 \%$ and less than 5 years only $37.3 \%$ [36].

The results presented above revealed that both the supply of dentures and their quality in both groups of seniors are unsatisfactory. The presence of removable overlay dentures primarily testifies to a lack of financial resources for the implementation of favorable dental prosthetic restorations, but more expensive. Prostheses overlaying in a non-physiological manner transmit chewing forces to the base and can contribute to the formation of bone atrophy, deterioration of the prosthetic base, pathological changes in the mucous membrane or loosening of teeth retained in the mouth $[21,35]$. Prolonged use of dental prostheses is worrying. It results in a detrimental effect on the tissues of the oral cavity [30]. Long-term use of dental prosthetic restorations causes a loss of their stability, the lack of aesthetic look and increase in patient dissatisfaction. According to the literature, duration of using removable overlay dentures should be about 5 years (for 3-8 years) $[12,14]$. After this period, dental prosthetic restorations require relining or replacement with new ones due to the material wear and atrophic changes occurring within the prosthetic base [37].

Teeth loss makes it necessary to provide patients with immediate prosthetic care, in order to restore proper chewing function, esthetic look and well-being. Yet, the dental care is often influenced by the patient's motivation, general condition as well his socio-economic context The maintenance of longterm, satisfactory functions of dental prosthetic restorations is affected by many factors, such as proper manufacture of prostheses, care for other natural teeth, periodontium and mucous membranes, the principles of oral hygiene and the appropriate use of dentures, i.e. control visits, cleaning and storage.

\section{CONCLUSIONS}

1. The supply of dentures in both groups of seniors is unsatisfactory.

2. It is observed too long use of dental prostheses in examined elderly from Lublin.

\section{REFERENCES}

1. Iacopino AM, Wathen WF. Geriatric prosthodontics: An overview. Part I Pretreatment considerations. Quintessence Int. 1993;24:259-66.

2. Marcus PA, Joshi A, Jones JA, Morgano SM. Complete edentulism and denture use for elders in New England. J Prosthet Dent. 1996;76:260-6.

3. Petersen PE, Yamamoto T. Improving the oral health of older people: the approach of the WHO Global Oral Health Programme. Comm Dent Oral Epidemiol. 2005;33:81-92. 
4. Trulsson U, Engstrand P, Berggren U, et al. Edentulousness and oral rehabilitation: experiences from the patients' perspective. Eur J Oral Sci. 2002;110:417-24.

5. Ünlüer Ş, Gökalp S, Doğan BG. Oral health status of the elderly in a residential home in Turkey. Gerodontology. 2007;24:22-9.

6. Borreani E, Jones K, Scambler S, Gallagher JE. Informing the debate on oral health care for older people: a qualitative study of older people's views on oral health and oral health care. Gerodontology. 2010;27:11-8.

7. Senpuku H, Sogame A, Inoshita E, et al. Systemic diseases in association with microbial species in oral biofilm from elderly requiring care. Gerontology. 2003;49:301-9.

8. Yoshihara A, Watanabe R, Hanada N, Miyazaki H. A longitudinal study of the relationship between diet intake and dental caries and periodontal disease in elderly Japanese subjects. Gerodontology. 2009;26:130-6.

9. Coleman P. Opportunities for nursing-dental collaboration: Addressing oral health needs among the elderly. Nurs Outlook. 2005;53:33-9.

10. Stawska B. Geriatric dentistry: dental needs, problems, and expectations of residents of care. Ann Acad Med Stetin. 2006;52:89-97.

11. Jundziłł-Bieniek E, Koczorowski R. Relationship between psychological factors and the state of removable dentures in elderly people. Dent Med Probl. 2008;45:130-5.

12. Koczorowski R, Gawriołek M, Siniawska J. Comparative analysis of the dental needs of nursing home residents in Poznań and Wielkopolska. Dent Forum. 2008;36:27-33

13. Bereznowski Z., Prośba-Mackiewicz M, Lasecka A, et al. Evaluation of teeth and dentures state and characteristic of prosthetic treatment needs in elderly people. Prosthetics. 2001;51: 91-6.

14. Namiot D, Sierpińska T, Gołębiewska M, Kobierska A. Evaluation of needs for removable dentures treatment in elderly patients. Prosthetics. 1995;45:295-300.

15. Rabiei M, Kasemnezhad E, Masoudi rad H, et al. Prevalence of oral and dental disorders in institutionalised elderly people in Rasht, Iran. Gerodontology. 2010;27:174-7.

16. Šimunković SK, Boras VV, Pandurić J, Žilić IA. Oral health among institutionalised elderly in Zagreb, Croatia. Gerodontology. 2005;22:238-41.

17. Gluhak C, Arnetzl GV, Kirmeier R, et al. Oral status among seniors in nine nursing homes in Styria, Austria. Gerodontology. 2010;27:47-52.

18. Frenkel H, Harvey I, Newcombe RG. Oral health care among nursing home residents in Avon. Gerodontology. 2000;17:33-8.

19. Knabe C, Kram P. Dental care for institutionalized geriatric patients in Germany. J Oral Rehabil. 1997;24:909-12.

20. Chalmers JM, Hodge C, Fuss JM, et al. The prevalence and experience of oral diseases in Adelaide nursing home residents. Aust Dent J. 2002;47:123-30
21. Krawczykowska H, Panek H, Makacewicz S. Analysis of prosthetics foundation in geriatric patients in aspect of overdenture. Prosthetics. 2005;55:424-9.

22. Kunert J, Brauman-Furmanek S. Assessment of the selected oral health parameters in elderly patients. Pol J Environ Stud. 2008;17:6A, 207-212.

23. Pasternak M, Chomyszyn-Gajewska M, Gołda T, et al. Use and need for dentures in connection with state of health of elderly people from Cracow and surroundings. Prosthetics. 2004;54:430-4.

24. Takehara S, Shimoyama K. Factors affecting the motivation for dental check-ups and anxiety in the elderly in Tokyo. Gerodontology. 2009;26:105-11

25. Vyšniauskaité S, Kammona N, Vehkalahti MM. Number of teeth in relation to oral health behaviour in dentate elderly patients in Lithuania. Gerodontology. 2005;22:44-51.

26. Pallegedara C, Ekanayake L. Tooth loss, the wearing of dentures and associated factors in Sri Lankan older individuals. Gerodontology. 2005;22:193-9.

27. Ekanayake L, Perera I. The association between clinical oral health status and oral impacts experienced by older individuals in Sri Lanka. J Oral Rehabil. 2004;31:831-6.

28. Shah N, Parkash H, Sunderam KR. Edentulousness, denture wear and denture needs of Indian elderly - a community-based study. J Oral Rehabil. 2004;31:467-76.

29. Moreira Rda S, Nico LS, Tomita NE. Oral health conditions among the elderly in southeastern São Paulo state. J Appl Oral Sci. 2009;17:170-8.

30. Koczorowski R, Gawriołek M, Siniawska J. Prosthetic needs of nursing home residents in Wielkopolska. Dent Med Probl. 2008;45:425-30.

31. Ozkan Y, Özcan M, Kulak Y, et al. General health, dental status and perceived dental treatment needs of an elderly population in Istanbul. Gerodontology. 2011;28:28-36.

32. Frączak B, Szteke O, Kijak E. The state of the stomatognathic system in a selected group of patients treated in the Department of Prosthetic Dentistry at the Pomeranian Medical Academy. P. 1. Prosthetics. 1996;46:222-6.

33. Kossioni AE. The prevalence of denture stomatitis and its predisposing conditions in an older Greek population. Gerodontology. 2011;28:85-90.

34. Jaworowska-Szczesiul E. The denture hygiene status in patients after prosthetic treatment. Prosthetics. 1994;44:32-4

35. Wiśniewska G, Loster BW, Majewski S. The fibrous type of hyperplastic inflammatory conditions of acrylic denture users - etiology and therapeutic procedure - based on authors clinical experience. J Stoma. 2004;57:543-8

36. Tokajuk G, Szyszko T, Miksza-Żyłkiewicz R, Guckler A. The prosthetic care of people above 55 years of age in a North-Eastern Macroregion. J Stoma. 1995; 48:35-8

37. Kurnatowska AJ, Bieniek J. The level of cariogenic bacteria in wearers of partial dentures. Prosthetics. 2006;56:130-5.

\section{Corresponding author}

Dr hab. n. med. Renata Chałas

Chair and Department of Conservative Dentistry and Endodontics,

Medical University of Lublin

7 Karmelicka Str., 20-081 Lublin, Poland

Email: renata.chalas@umlub.pl 